\title{
CD8 $^{+}$Resident Memory T Cells and Viral Infection
}

\author{
Xuejie $\mathrm{Wu}^{1 \dagger}$, Pin $\mathrm{Wu}^{2 \dagger}$, Yifei Shen ${ }^{3}$, Xiaodong Jiang ${ }^{3}$ and Feng $\mathrm{Xu}{ }^{1 *}$ \\ ${ }^{1}$ Department of Infectious Diseases, The Second Affiliated Hospital, Zhejiang University School of Medicine, Hangzhou, \\ China, ${ }^{2}$ Department of Thoracic Surgery, The Second Affiliated Hospital, Zhejiang University School of Medicine, Hangzhou, \\ China, ${ }^{3}$ Department of Immunobiology, Yale University School of Medicine, New Haven, CT, United States
}

\section{OPEN ACCESS}

Edited by:

Kamal M. Khanna,

New York University, United States

Reviewed by:

Brian S. Sheridan,

Stony Brook University, United States

Georg Gasteiger,

Julius-Maximilians-Universität,

Germany

${ }^{*}$ Correspondence:

Feng Xu

xufeng99@zju.edu.cn

tThese authors have contributed equally to this work

Specialty section:

This article was submitted to Immunological Memory,

a section of the journal

Frontiers in Immunology

Received: 01 April 2018

Accepted: 24 August 2018 Published: 19 September 2018

Citation:

Wu X, Wu P, Shen Y, Jiang $X$ and Xu F (2018) CD8 ${ }^{+}$Resident Memory $T$ Cells and Viral Infection.

Front. Immunol. 9:2093

doi: 10.3389/fimmu.2018.02093
Tissue-resident memory $\mathrm{T}$ (Trm) cells are a subset of recently identified memory $\mathrm{T}$ cells that mainly reside and serve as sentinels in non-lymphoid peripheral tissues. Unlike the well-characterized circulating central memory $\mathrm{T}(\mathrm{Tcm})$ cells and effector memory $\mathrm{T}$ (Tem) cells, Trm cells persist in the tissues, do not recirculate into blood, and offer immediate protection against pathogens upon reinfection. In this review, we focus on $\mathrm{CD}^{+}$Trm cells and briefly introduce their characteristics, development, maintenance, and function during viral infection. We also discuss some unresolved problems, such as how CD8 ${ }^{+}$ Trm cells adapt to the local tissue microenvironment, how Trm cells interact with other immune cells during their development and maintenance, and the mechanisms by which $\mathrm{CD}^{+}$Trm cells confer immune protection. We believe that a better understanding of these problems is of great clinical and therapeutic value and may contribute to more effective vaccination and treatments against viral infection.

Keywords: memory T cells, tissue-resident memory T cells, microenvironment, viral infection, immune response

\section{INTRODUCTION}

Upon infection, the host immune system initiates immune responses against invading pathogens, a process in which both innate and adaptive immune cells participate sequentially and synergistically. Pathogen-specific memory T cells and B cells persist long after the infection has been cleared (1-3). Until recently, memory $\mathrm{T}$ cells had been categorized into central memory $\mathrm{T}(\mathrm{Tcm})$ cells and effector memory $\mathrm{T}(\mathrm{Tem})$ cells. Tcm cells are a small population of memory $\mathrm{T}$ cells that circulate between the secondary lymphoid organs (SLOs) and the blood. They are long-lived and can be activated rapidly upon reencountering their cognate antigen in SLOs. Tem cells have been proposed to migrate through the blood, lymphoid and non-lymphoid tissues (NLT). They kill pathogens via a variety of effector mechanisms and disappear gradually after the pathogens have been eliminated (4-8).

Resident memory $\mathrm{T}$ (Trm) cells, a third population of memory $\mathrm{T}$ cells, have been identified recently, especially in barrier tissues and SLOs $(6,9-12)$. They persist permanently in these tissues and do not recirculate into the blood. They can mount a rapid immune response upon reencountering the same pathogen and restrict infection within the local tissue sites (11-14). In addition, emerging data indicate that Trm cells are also involved in tumor immunosurveillance (15). CD103 and CD69 have been considered as two common surface markers in distinguishing Trm cells from other memory $\mathrm{T}$ cells (16-20). However, some studies have demonstrated that $\mathrm{CD}^{-} 9^{-}$or $\mathrm{CD} 103^{-}$Trm cells also exist in non-lymphoid peripheral tissues (21-23). This indicates that the development and maintenance of Trm cells, including their phenotypic characteristics, are tightly regulated by local microenvironment $(24,25)$. 
While both $\mathrm{CD}^{+}$and $\mathrm{CD} 8^{+}$Trm cells have been identified, $\mathrm{CD}^{+}$Trm cells are more extensively investigated in viral infection (26). CD8 ${ }^{+}$Trm cells that arise through infections due to a variety of pathogens have been identified and characterized in many studies. For example, after acute herpes simplex virus (HSV) infection, $\mathrm{CD}^{+}{ }^{+}$Trm cells are generated and retained in the skin to protect against reinfection of HSV (27). Skin CD ${ }^{+}$Trm cells produce abundant interferon (IFN) $-\gamma$ and tumor necrosis factor (TNF)- $\alpha$ following cognate antigen stimulation and are responsible for efficient control of vaccinia virus (VACV) re-infection (12). Using intraglandular infection, Thom et al. demonstrated that $\mathrm{CD} 8^{+}$Trm cells immediately defend the host against local murine cytomegalovirus (MCMV) infection, despite active viral immune evasion (28). Influenza virus-specific CD8 ${ }^{+}$ Trm cells in the nasal epithelia prevent the transmission of influenza virus from the upper respiratory tract to the lung (29). These cells are also sequestered in the walls of the large airways and are crucial for ideal cross-protection against pulmonary influenza virus infection (30-32). Intranasal vaccination of liveattenuated influenza virus generates virus-specific $\mathrm{CD}^{+}{ }^{+} \mathrm{Trm}$ cells as well (33). Moreover, both mouse and human respiratory syncytial virus (RSV) specific $\mathrm{CD}^{+}$Trm cells are associated with control of lung RSV infection $(34,35)$. Immune responses of human immunodeficiency virus (HIV)-1-specific CD8 ${ }^{+}$Trm cells are the strongest in patients whose immune systems are able to naturally control HIV-1 infection, suggesting the involvement of these cells in local anti-HIV immunity (36). In immunosuppressed renal transplant recipients (RTRs), impaired effector differentiation of polyomavirus $\mathrm{BK}$ (BKPyV) major capsid protein (VP1)-specific CD8 ${ }^{+}$Trm cells is associated with $\mathrm{BKPyV}$-induced interstitial nephritis (BKVN), which is caused by $\mathrm{BKPyV}$ reactivation after initial control of the virus (37). In addition to non-lymphoid peripheral tissues, CD ${ }^{+}$Trm cells are also embedded in thymus and mediate local immunity against lymphocytic choriomeningitis virus (LCMV) reinfection through degranulation and cytokine (IFN- $\gamma$ and TNF- $\alpha$ ) production (38). Together, all these data indicate that $\mathrm{CD}^{+}$Trm cells play an important role in anti-viral immunity not only in non-lymphoid peripheral tissues but also in lymphoid tissues.

In this review, we mainly focus on $\mathrm{CD}^{+}$Trm cells and briefly introduce their characteristics, development, maintenance and functions in viral infection. We also discuss the impact of local tissue microenvironment on determining phenotypes of $\mathrm{CD} 8^{+}$ Trm cells, the mutual conversion of Trm, Tem, and Tcm cells, the mechanisms of long-term maintenance of Trm cells, and crucial steps in initiating $\mathrm{CD}^{+}{ }^{+}$Trm cell immune responses. To understand these fundamental questions and further illustrate the underlying mechanisms will help find better strategies for control of viral infection.

\section{CHARACTERISTICS OF CD8 ${ }^{+}$RESIDENT MEMORY T CELLS}

Unlike circulating $\mathrm{CD} 8^{+} \mathrm{Tcm}$ and Tem cells, $\mathrm{CD} 8^{+}$Trm cells locate permanently in the tissues and do not recirculate into the blood (39). More importantly, CD8 ${ }^{+}$Trm cells are distributed widely in non-lymphoid peripheral tissues including the skin, lung, gastrointestinal tract, female reproductive tract (FRT), brain, liver, kidney, salivary glands, etc (16, 18, 40-44). Recently, some studies reported that $\mathrm{CD}^{+}$Trm cells also persist in lymphoid tissues including SLOs and thymus $(11,38,45)$. The broad distribution of Trm cells indicates their importance in local immunity.

$\mathrm{CD}^{+}$Trm cells in non-lymphoid tissues were initially defined as $\mathrm{CD}_{103}{ }^{+} \mathrm{CD}^{+} 9^{+}(16-20)$. But later CD69- ${ }^{-}$and CD103- Trm cells were also identified, suggesting that CD69 and CD103 may not be the definite markers of Trm cells (21-23). Interestingly, to some extent these CD103 or CD69 negative CD8 ${ }^{+}$Trm cells are different from those positive populations. For example, both $\mathrm{CD}^{+}{ }^{+}$and $\mathrm{CD}^{-} 9^{-} \mathrm{CD}^{+}$Trm cells were identified in the pancreas, salivary gland (SG) and FRT, but they have different population sizes (21). In Yersinia pseudotuberculosis (Yptb) oral infection model, CD103 ${ }^{+} \mathrm{CD} 8^{+}$Trm cells are mainly localized in the intestinal epithelium (IEL) and lamina propria (LP) while $\mathrm{CD} 103^{-} \mathrm{CD}^{+}$Trm cells mainly reside in LP and are close to the crypts (46). $\mathrm{CD} 103^{+} \mathrm{CD}^{+}$and $\mathrm{CD}^{+} 03^{-} \mathrm{CD}^{+}$ Trm cells are found preferentially in epidermis and in dermis, respectively (18). After murine polyomavirus (MuPyV) infection, brain $\mathrm{CD}_{103}{ }^{+} \mathrm{CD}^{+}$Trm cells uniformly express programmed cell death protein 1 (PD-1), in contrast to $\mathrm{CD} 103^{+} \mathrm{CD} 8^{+}$Trm cells in the spleen, which are PD-1 negative (23). In addition, $\mathrm{CD}^{+}$Trm cells within intestinal mucosa express a variety of distinct molecules that distinguish themselves from memory $\mathrm{T}$ cells in SLOs: up-regulate CD28 and CD11c and rapidly produce IFN- $\gamma$ after reactivation by antigen (47).

Like circulating $\mathrm{Tcm}$ and Tem cells, $\mathrm{CD}^{+}$Trm cells in different tissues also have distinct transcriptional programs. Lung, skin or gut $\mathrm{CD}^{+}$Trm cells have a unique core transcriptional profile with 25-127 specific transcripts, which are progressively engaged during differentiation (18). Liver, known as an immune tolerance organ, retains large numbers of $\mathrm{CD}^{+}$Trm cells that express low levels of sphingosine 1phosphate receptor-1 (S1PR1) and Krüppel-like Factor 2 (KLF2); interestingly, most of these $\mathrm{CD}^{+}$Trm cells in the liver are CXCR6 and granzyme positive, and are localized in portal fields, central veins, and parenchymal zones in CHB patients (48). $\mathrm{CD}^{+}$Trm cells isolated from the brain possess altered molecular signatures including chemokines and chemokine receptors (upregulation of CCL3, CXCL10, and CCL4 and down-regulation of CX3CR1 and CCL9), transcription factors (down-regulation of eomes, Tcf-1, lef1, and T-bet and up-regulation of IFITM3, Irf4, and Isg20) and several inhibitory receptors (CTLA-4 and PD1) after recombinant vesicular stomatitis virus (VSV) infection (49). Similar to mouse CD8 ${ }^{+}$Trm cells, human CD8 ${ }^{+}$Trm cells up-regulate ITGA1 (CD49a), ICOS, and the transcription factor IRF4 but down-regulate eomes $(43,50)$.

$\mathrm{CD}^{+}$Trm cells can mount a rapid and robust immune response against reinfection, which is thought to be critical for the efficacy of vaccination. Some functional differences between Trm populations among children, adults, and the elderly have been observed (51). Compared to adults, fewer lung $\mathrm{CD} 8^{+}$ and $\mathrm{CD}^{+}{ }^{+}$Trm cells are established after influenza infection during infancy, which may be associated with more serious or 
frequent respiratory infections and reduced vaccine responses. The difference between adult and infant Trm cell establishment can be attributed to increased T-bet expression in infant $\mathrm{T}$ cells after activation, as is demonstrated in both murine and human models (52).

Taken together, current studies indicate that $\mathrm{CD}^{+}$Trm cells in different tissues share some common characteristics in phenotype and functions. However, they also have distinct properties in phenotypes, transcriptional profiling and function as well. The differences among them may be caused by the regulation of their unique tissue microenvironment, which affects their developmental fates.

\section{DEVELOPMENT OF CD8 ${ }^{+}$RESIDENT MEMORY T CELLS}

How memory $\mathrm{T}$ cells are generated is a fundamental question in the research field of immunological memory. For classical Tcm and Tem cell development, there are several differentiation hypotheses including linear differentiation model and asymmetric division model (53-55). CD127 ${ }^{+}$killer cell lectin-like receptor $\mathrm{G} 1$ (KLRG1)- ${ }^{-} \mathrm{CD}^{+} \mathrm{T}$ cells have been demonstrated to be memory precursor effector cells (MPECs) (56). Whether $\mathrm{CD}^{+}$Trm cells also have precursors and what the underlying transcriptional mechanisms in $\mathrm{CD}^{+}{ }^{+}$Trm cell development are critical questions in the research field of Trm cells.

Mackay et al. (18) recently found that $\mathrm{KLRG}^{-}$, not $\mathrm{KLRG}^{+}$, activated $\mathrm{CD}^{+} \mathrm{T}$ cells can develop into skin epitheliuminfiltrating $\mathrm{CD}_{103}{ }^{+} \mathrm{CD}^{+}{ }^{+}$Trm cells. $\mathrm{CD} 127^{+} \mathrm{KLRG}^{-} \mathrm{CD} 8^{+}$ $\mathrm{T}$ cells have been demonstrated to be the intestinal $\mathrm{CD} 8^{+}$Trm precursors in an oral Listeria monocytogenes infection model (57). However, $\mathrm{CD}_{127^{+}} \mathrm{KLRG}^{+}$effector $\mathrm{CD} 8^{+} \mathrm{T}$ cells may lose KLRG1 and differentiate into all memory $\mathrm{T}$ cell lineages including CX3CR1 ${ }^{-}$Trm cells $(58,59)$. Gerlach et al. recently demonstrated that CX3CR1 is a critical chemokine receptor correlated with $\mathrm{CD} 8^{+} \mathrm{T}$ cell differentiation and further suggested that $\mathrm{CD}^{+}{ }^{+}$Trm cells are derived from $\mathrm{CX} 3 \mathrm{CR} 1^{-}$activated $\mathrm{CD} 8^{+}$ $\mathrm{T}$ cells (59). It was reported that DC NK lectin group receptor1 (DNGR-1) $^{+}$dendritic cells (DCs) may prime naïve $\mathrm{CD}^{+} \mathrm{T}$ cells to become Trm cell precursors in draining lymph nodes (dLNs), but are not required for Trm differentiation in the skin. Expression of interleukin (IL)-12, IL-15, and CD24 is essential for optimal formation of Trm cells (60). To date, how DC subsets play an important role in generating $\mathrm{CD}^{+}$Trm cell precursor is still unclear. In addition, it is known that $\mathrm{CD} 4^{+} \mathrm{T}$ cell help is required for DCs to induce a robust effector $\mathrm{CD} 8^{+} \mathrm{T}$ cell response (61). In the absence of $\mathrm{CD}^{+} \mathrm{T}$ cells, fewer $\mathrm{CD} 103^{+}$ $\mathrm{CD} 8^{+}$Trm cells are developed in the lungs. Reduced expression of CD103 results from increased expression of the transcription factor T-bet in "unhelped" lung Trm cells. Generation of CD103 ${ }^{+}$ $\mathrm{CD} 8^{+}$Trm cells also requires $\mathrm{CD} 4^{+} \mathrm{T}$ cell-derived IFN- $\gamma$ (62). However, in acute VACV skin infection mouse model we did not see a reduction of skin $\mathrm{CD}^{+}{ }^{+}$Trm cells in the absence of CD4 ${ }^{+}$ $\mathrm{T}$ cells, though the function of skin $\mathrm{CD} 8^{+}$Trm cells was found to be partially impaired (12). Moreover, we also did not see any significant reduction of $\mathrm{CD} 8^{+}$Trm cells in the absence of IFN $\gamma$ (our unpublished data).

Several distinct transcription factors or proteins are involved in the development and homeostasis of $\mathrm{CD}^{+}$Trm cells. For instance, $\mathrm{CD}^{+}$Trm cells can utilize the transcription factor AhR to maintain residency in the epidermis and compete with dendritic epidermal $\gamma \delta \mathrm{T}$ cells for space within the epidermal niche (63). In mice, development of $\mathrm{CD}^{+}$Trm cells in the skin, gut, liver, and kidney requires cooperation of transcription factors Hobit and Blimp1 (64). Moreover, the function and development of Trm cells can be influenced by nuclear receptor subfamily 4 group A member 1 (NR4A1) and ATP-binding cassette (ABC) transporters (65). Using computational and pooled in vivo RNA interference screens, Milner et al. showed that the transcription factor Runx3 also plays a crucial role in the differentiation and homeostasis of $\mathrm{CD}^{+}$Trm cells (66). Purinergic receptor P2RX7 has recently been found to be involved in the generation of $\mathrm{CD}^{+}$Trm cells in various nonlymphoid sites (67). In addition to local antigen presentation, intrinsic $4-1 \mathrm{BB}$ signals are essential in mediating the generation of $\mathrm{CD}^{+}$Trm cells in the lung during influenza infection $(31,68$, 69).

Furthermore, peripheral tissue microenvironment is crucial in shaping the development of $\mathrm{CD} 8^{+}$Trm cells. Hair follicle derived cytokines such as IL-7 and IL-15 play critical roles in skin Trm cell homeostasis (70), while transforming growth factor (TGF)- $\beta$ promotes the formation of kidney $\mathrm{CD} 8^{+}$Trm cells by enhancing expression of E- and P-selectin and chemokine receptor CXCR3, which mediate the extravasation of effector T cells (71). Despite the involvement of TGF- $\beta$ in Trm development, Smad4, which is required for normal differentiation of circulating memory $\mathrm{T}$ cells, is not necessary for Trm cell differentiation (72). Adhesionand degranulation-promoting adapter protein (ADAP) integrin facilitates $\mathrm{CD}^{+}$Trm cells formation in non-lymphoid tissues (73). Formalin-inactivated RSV combined with CpG (an agonist of TLR9) and L685,458 (an inhibitor of Notch signaling) promote protective $\mathrm{CD}^{+}$Trm cells in the lungs (74). Additionally, brain TGF- $\beta$ producing regulatory $\mathrm{T}$ cells (Tregs) are found to be involved in $\mathrm{CD}^{+}$Trm cell accumulation and granzyme $\mathrm{B}$ production after West Nile virus (WNV) and MCMV infection $(75,76)$. Besides non-specific stimulation, specific stimulation such as local antigen in skin is also required for the formation of functional $\mathrm{CD}^{+}$Trm cells and amplifies their generation. Although recruitment of activated $\mathrm{CD}^{+} \mathrm{T}$ cells to VACV infected skin is antigen independent, significant increase in Trm formation is observed when local antigen is present (77). In skin that has been previously infected, antigen-dependent crosscompetition is involved in shaping the repertoire of polyclonal antiviral Trm cells (78). Secondary Trm cells form from both preexisting Trm cells and Trm precursors recruited from the blood in response to local antigen presence (79). Transient introduction of antigen results in the generation of Trm in the brain via an intracranial dendritic cell immunization regimen (80). However, local inflammation in the skin and mucosa alone can drive recruitment of effector populations and direct their conversion to $\mathrm{CD}^{+}$Trm cells (24). Similarly, differentiation and maintenance of $\mathrm{CD}^{+}$Trm cells are antigen-independent in small intestine, kidney, pancreas, stomach, heart, and FRT of mice $(81,82)$. 


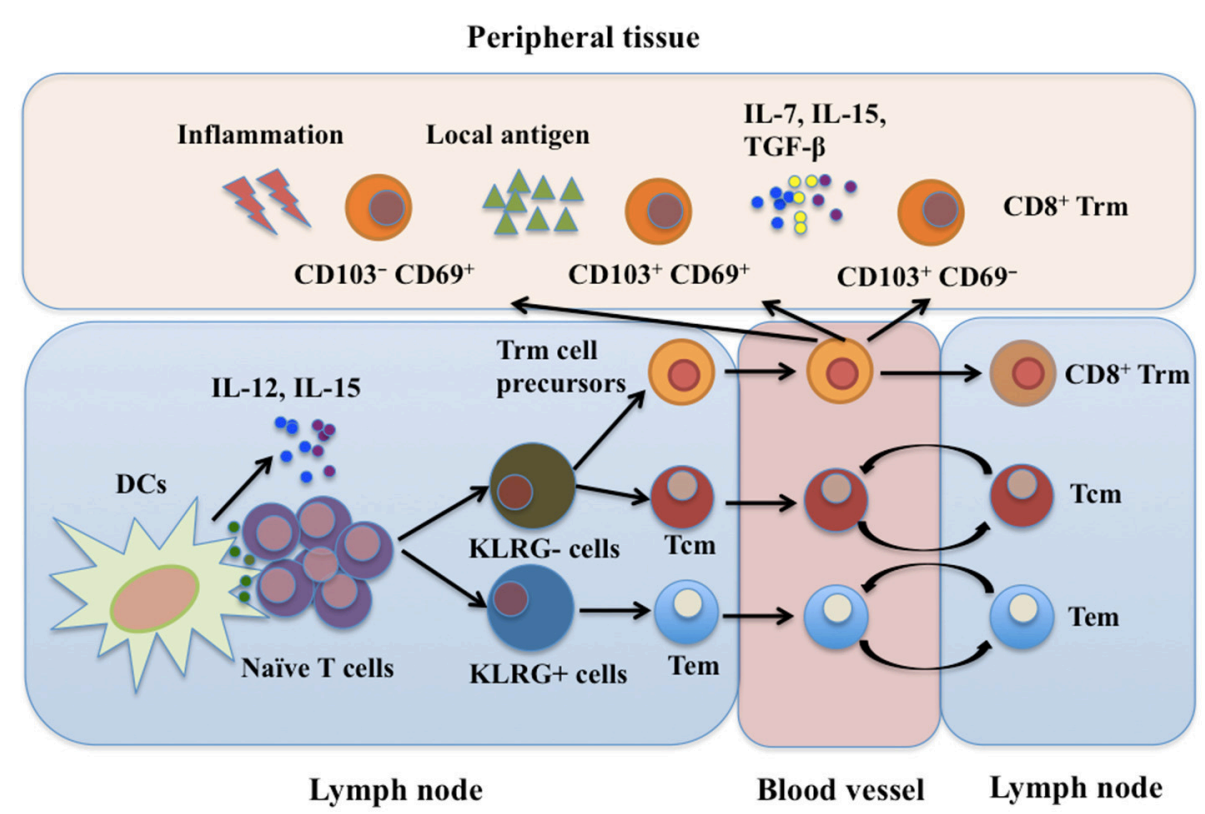

FIGURE 1 | CD8 ${ }^{+}$Trm cell development. Trm, Tem, and Tcm cells are derived from the same naïve T cell clone upon activation in SLOs. CD8 ${ }^{+}$Trm cell precursors migrate into peripheral tissues as well as SLOs where they differentiate into Trm cells. Currently, at least three subtypes of CD8 ${ }^{+}$Trm cells have been identified: $\mathrm{CD} 3^{+} \mathrm{CD}^{+}{ }^{+}, \mathrm{CD} 103^{+} \mathrm{CD}^{-}{ }^{-}$, and CD103- CD69+ Trm cells. Local microenvironment, including cytokines, local antigens and inflammatory mediators, is important for development of CD8 ${ }^{+}$Trm cells. SLOs, secondary lymphoid organs; Tcm, central memory T cells; Tem, effector memory T cells; Trm, resident memory T cells; DCs, dendritic cells; LN, Iymph node; IL-7, interleukin-7; IL-12, interleukin-12; IL-15, interleukin-15; TGF- $\beta$, transforming growth factor- $\beta$; KLRG, killer cell lectin-like receptor $\mathrm{G}$.

$\mathrm{CD}^{+}$Trm cells have long been thought to reside exclusively in non-lymphoid tissues. However, in SLOs such as the splenic marginal zone, red pulp, and lymph node sinuses, $\mathrm{CD}^{+}{ }^{+}$Trm cells are also present. These Trm cells can be derived from the skin or mucosa after restimulation (11, 45). Although great progress has been made in characterizing $\mathrm{CD}^{+}$Trm cell development, the exact mechanisms are still unclear. Both intrinsic and extrinsic factors are involved in the development of $\mathrm{CD}^{+}$Trm cells. More details need to be known before therapeutically manipulating $\mathrm{CD}^{+}$Trm cell development, which is important for the control of viral infection and vaccine design. A developmental scheme for $\mathrm{CD} 8^{+}$Trm cells is shown in Figure 1.

\section{MAINTENANCE OF CD8 ${ }^{+}$RESIDENT MEMORY T CELLS IN LOCAL MICROENVIRONMENT}

IL-7 and IL-15 are two critical cytokines required for the survival and homeostasis of classical memory $\mathrm{CD}^{+} \mathrm{T}$ cells $(17,83)$. In some but not all peripheral tissues, IL-15 is required for the survival of $\mathrm{CD}^{+}$Trm cells $(18,84)$. This suggests that other factors may also be involved in the maintenance of Trm cells. TGF- $\beta$ is not only critical for Trm formation but also required for skin and gut Trm maintenance $(18,25)$. Expression of TGF- $\beta$ and IL-15 are controlled by T-box transcription factors (TFs) Eomes and T-bet (85). Retention of intestinal $\mathrm{CD}^{+}{ }^{+}$Trm cells is partly associated with integrins $\alpha \mathrm{E} \beta 7$ and $\alpha 1$ as well as $\mathrm{CD} 69$, whose expression is induced by TGF- $\beta$ (25). CD69 may retain Trm cells in the skin by blocking sphingosine-1-phosphate (S1P)-regulated tissue egress (86). Downregulation of S1PR1 is controlled by the transcription factor Kruppel-like factor 2 (KLF2) (87). However, CD69 is not required for Trm cell retention in the lung when they have entered the Trm cell niches (88). In addition, E-cadherin and integrin $\alpha 4 \beta 1$ promote $\mathrm{CD}^{+}$Trm cells accumulation in salivary glands $(89,90)$.

Some other factors also play important roles in maintenance of Trm cells. For example, exogenous free fatty acid (FFA) can be used by skin $\mathrm{CD}{ }^{+}$Trm cells via fatty-acid-binding proteins (FABP4) 4 and FABP5 for their maintenance (91). Deletion of CCR2 ${ }^{+}$IL-12-producing cells, most of which are macrophages, reduces the size of the $\mathrm{CD}_{103^{-}} \mathrm{CD}^{+}$Trm population during infection, suggesting that macrophages or the mediators they produce may be involved in Trm cell persistence (22). Although local antigen contributes to in situ proliferation of Trm cells $(77,78)$, it is not indispensable for local Trm cell persistence, indicating a dependence on the local microenvironment for Trm function and survival (80). Moreover, $\mathrm{CD}^{+}$Trm and lymph node $\mathrm{Tcm}$ cell clones are generated from the same naïve $\mathrm{T}$ cell precursor after skin immunization (92). Therefore, $\mathrm{CD}^{+} \mathrm{Tcm}$ could be a potential reservoir for $\mathrm{CD}^{+}$Trm cells upon reinfection. In addition, reactivation of Trm cells recruit recirculating memory $\mathrm{T}$ cells that undergo antigen-independent Trm cell differentiation in situ (82). In brain, B7-H1 has a critical role in the maintenance of $\mathrm{CD}^{+}$Trm cells (93). 
Understanding how Trm cells maintain long-term residency within barrier tissues will enable the manipulation of these cells in vitro. A scheme for possible mechanisms of $\mathrm{CD}^{+}$Trm cell maintenance is shown in Figure 2.

\section{PROTECTIVE MECHANISMS OF CD8 ${ }^{+}$ RESIDENT MEMORY T CELLS IN ANTIVIRAL IMMUNITY}

The importance of $\mathrm{CD}^{+}$Trm cells in peripheral tissue protection has been widely recognized. Skin $\mathrm{CD}^{+}$Trm cells serve as sentinels and continuously migrate through the epidermis. They change size, length, and direction of dendrites, which are independent of skin inflammatory state. They quickly identify antigen-expressing cells in vivo and initiate in situ immune responses (94). The CXCL17/CXCR8 and CXCL10/CXCR3 chemokine pathways are involved in $\mathrm{CD}^{+}$Trm cell mobilization to infected barrier tissues $(95,96)$. The rapid control of viral infection is related to abundant IFN- $\gamma$ and TNF- $\alpha$ produced by $\mathrm{CD}^{+}$Trm cells following cognate antigen stimulation (12, 97-100). After LCMV reinfection in mice, brain $\mathrm{CD}^{+}$Trm cells rapidly produce IFN- $\gamma$ and perforin and prevent fatal brain infection in a manner independent of circulating $\mathrm{CD}^{+}$memory $\mathrm{T}$ cells. Presentation of cognate antigen on major histocompatibility complex (MHC)-I is required for brain Trm cell protective immunity (100). Control of the female mice genital HSV-2 infection by $\mathrm{CD}^{+} \mathrm{Trm}$ cells requires expression of MHCI on $\mathrm{CD}_{301 \mathrm{~b}^{+}} \mathrm{DCs}$ in the lamina propria (99). However, infected epidermal cells may directly present viral antigen to $\mathrm{CD}^{+} \mathrm{T}$ cells to induce cytokine production, which may also be involved in the activation of $\mathrm{CD}^{+}$Trm cells (94, 101). It is well-known that activated $\mathrm{T}$ cells express inhibitory molecules (102). For example, activated intrahepatic $\mathrm{CD}^{+}$Trm cells express both PD-1 and CD39 after sequential IL-15 or antigen exposure. These inhibitory molecules combined with IL-2 and IFN- $\gamma$ promote liver CD8 ${ }^{+}$Trm cell survival while contribute to local non-cytolytic hepatic immunosurveillance (103).

Reactivation of $\mathrm{CD}^{+}$Trm cells by peptide challenge can trigger strong antiviral immunity against antigenically unrelated pathogens. In addition to inducing a number of broadly active antiviral and antibacterial genes, reactivated Trm cells orchestrate both innate and adaptive immune components including recruitment of recirculating $\mathrm{CD}^{+}{ }^{+} \mathrm{T}$ cells, $\mathrm{CD} 8^{+} \mathrm{T}$ cells and B cells, maturation of DCs, and activation of natural killer (NK) cells to develop a "pathogen alert" state. Achievement of these functions relies on IFN- $\gamma$, TNF- $\alpha$, and IL-2R $\beta$-dependent cytokines (104-106). IFN- $\gamma$ secreted by activated CD8 ${ }^{+}$Trm cells enhances expression of vascular cell adhesion molecule1 (VCAM-1) on vascular endothelium, which contributes to recruitment of $\mathrm{CD}^{+}{ }^{+} \mathrm{T}$ cells, $\mathrm{CD} 8^{+} \mathrm{T}$ cells, and $\mathrm{B}$ cells to local tissues. In addition, TNF- $\alpha$ and IL-2R $\beta$-dependent cytokines are essential for DC maturation and granzyme B upregulation in both $\mathrm{NK}$ cells and bystander memory $\mathrm{CD} 8^{+}$ $\mathrm{T}$ cells, respectively $(105,107)$. However, the crucial steps for the initiation of $\mathrm{CD}^{+}$Trm cell immune responses are still obscure. Further exploration should be focused on how to optimize their antiviral functions. A scheme for possible mechanisms of $\mathrm{CD}^{+}{ }^{+}$Trm cells in viral protection is shown in Figure 3.

\section{MAJOR OPEN QUESTIONS}

It is now clear that $\mathrm{CD}^{+} \mathrm{Trm}$ cells play an important role in peripheral immune surveillance and protection against invading pathogens, especially in viral infection. The diversities of $\mathrm{CD} 8^{+}$ Trm cells may be caused by different tissue microenvironments.

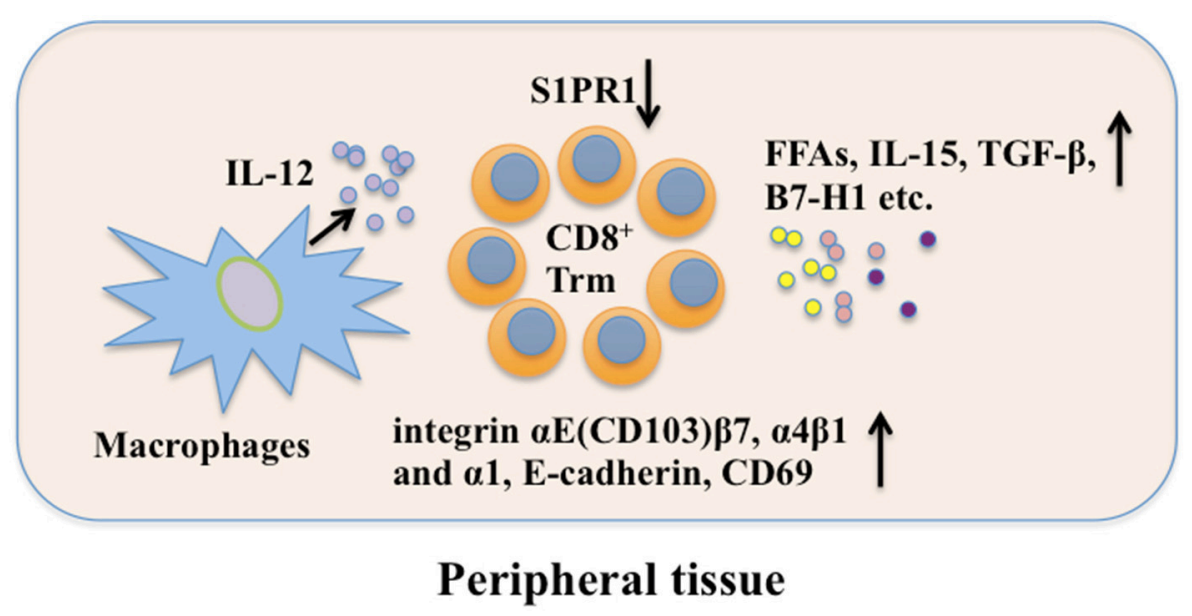

FIGURE 2 | CD8 ${ }^{+}$Trm cell maintenance. Local factors in peripheral tissue are crucial in long-term maintaining CD8 ${ }^{+}$Trm cells. CD69, E-cadherin, and integrin promote retention of $\mathrm{CD}^{+}$Trm while S1PR1 can mediate CD8 ${ }^{+}$Trm cell tissue egress. FFAs, IL-15, TGF- $\beta$, and B7-H1 are involved in CD8 ${ }^{+}$Trm cell maintenance. Besides, macrophages may promote CD8 ${ }^{+}$Trm cell maintenance through secreting IL-12. FFAs, free fatty acids; S1PR1, sphingosine 1-phosphate receptor-1; IL-12, interleukin-12; IL-15, interleukin-15; TGF- $\beta$, transforming growth factor- $\beta$; B7-H1, B7 homolog 1 ; Trm, resident memory T cells. 


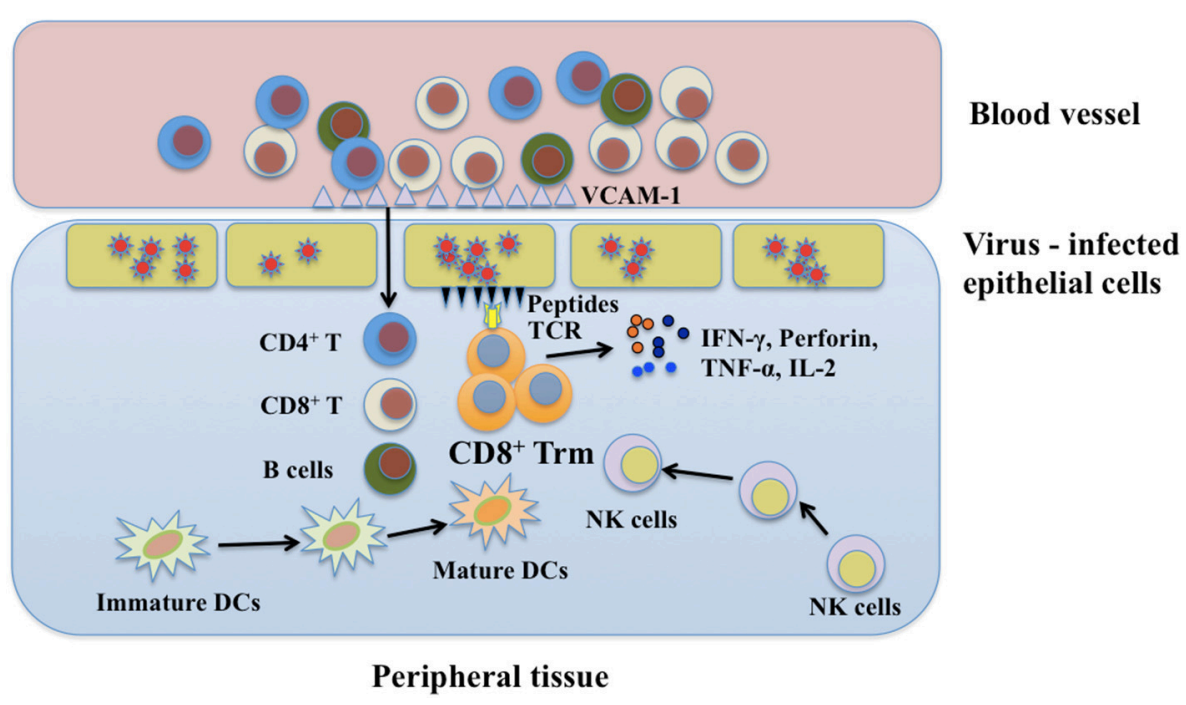

FIGURE 3 | The protective function of $\mathrm{CD}^{+}{ }^{+}$Trm cells in viral infection. Upon encountering the same pathogen, $\mathrm{CD} 8^{+}$Trm cells can be reactivated immediately and secrete cytokines in which IFN- $\gamma$ may help recruit immune cells from blood stream via enhancing expression of endothelial vessel addressin. These immune cells include $\mathrm{CD} 4^{+} \mathrm{T}$ cells, $\mathrm{CD} 8^{+} \mathrm{T}$ cells, and B cells. Besides, NK cells and immature DCs in local tissue can also be recruited to the place where CD8 ${ }^{+}$Trm cells are reactivated. $C D 8^{+}$Trm cells cooperate with these immune cells to synergistically combat with viruses by secreting perforin, IFN- $\gamma$, and TNF- $\alpha$. Trm, resident memory $T$ cells; DCs, dendritic cells; NK, natural killer; IFN- $\gamma$, interferon- $\gamma$; TNF- $\alpha$, tumor necrosis factor- $\alpha$; IL-2, interleukin-2; VCAM-1, vascular cell adhesion molecule-1.

The exact roles of different components involved in the process of $\mathrm{CD}^{+}{ }^{+}$Trm cell mediated immunity are still obscure. Although great progress has been made in $\mathrm{CD} 8^{+}$Trm cell research, several problems need to be further explored: What is the origin of $\mathrm{CD}^{+}$ $\mathrm{T}$ cell precursor in dLNs? What are the tissue-specific adaptations of $\mathrm{CD}^{+}$Trm cell development? What is the role of local tissue antigen-presenting cells in $\mathrm{CD}^{+}$Trm cell differentiation vs. recall reaction? How are $\mathrm{CD} 8^{+}$Trm cells regulated during reactivation? We believe that the strategies that modulate the functions of $\mathrm{CD}^{+}$Trm cells will be helpful for the control of viral infection if more details about $\mathrm{CD} 8^{+}$Trm cells are unraveled.

\section{REFERENCES}

1. Zinkernagel RM. Immunology taught by viruses. Science (1996) 271:173-8. doi: 10.1126/science.271.5246.173

2. Gourley TS, Wherry EJ, Masopust D, Ahmed R. Generation and maintenance of immunological memory. Semin Immunol. (2004) 16:323-33. doi: 10.1016/j.smim.2004.08.013

3. Dorner T, Radbruch A. Antibodies and B cell memory in viral immunity. Immunity (2007) 27:384-92. doi: 10.1016/j.immuni.2007.09.002

4. Sallusto F, Lenig D, Forster R, Lipp M, Lanzavecchia A. Two subsets of memory $\mathrm{T}$ lymphocytes with distinct homing potentials and effector functions. Nature (1999) 401: 708-12. doi: 10.1038/44385

5. Masopust D, Vezys V, Marzo AL, Lefrancois L. Preferential localization of effector memory cells in nonlymphoid tissue. Science (2001) 291: 2413-7. doi: $10.1126 /$ science. 1058867

6. Masopust D, Schenkel JM. The integration of T cell migration, differentiation and function. Nat Rev Immunol. (2013) 13:309-20. doi: 10.1038/nri3442

7. Klonowski KD, Marzo AL, Williams KJ, Lee SJ, Pham QM, Lefrançois L. CD8T cell recall responses are regulated by the tissue tropism

\section{AUTHOR CONTRIBUTIONS}

XW and PW drafted the primary manuscript and figures. FX, YS, and XJ designed and corrected the manuscript. All the authors have read and approved the final manuscript.

\section{ACKNOWLEDGMENTS}

This study was supported by grants from the National Natural Science Foundation of China (81400621, 81370176, and $81572800)$ and the Major Science and Technology Special Project of Zhejiang Province (2014C03033).

of the memory cell and pathogen. J Immunol. (2006) 177:6738-46. doi: 10.4049/jimmunol.177.10.6738

8. Kaech SM, Wherry EJ. Heterogeneity and cell-fate decisions in effector and memory $\mathrm{CD}^{+} \mathrm{T}$ cell differentiation during viral infection. Immunity (2007) 27:393-405. doi: 10.1016/j.immuni.2007. 08.007

9. Gebhardt T, Whitney PG, Zaid A, Mackay LK, Brooks AG, Heath WR, et al. Different patterns of peripheral migration by memory $\mathrm{CD} 4^{+}$and $\mathrm{CD} 8^{+} \mathrm{T}$ cells. Nature (2011) 477:216-9. doi: 10.1038/nature10339

10. Teijaro JR, Turner D, Pham Q, Wherry EJ, Lefrançois L, Farber DL. Cutting edge: tissue-retentive lung memory CD4 T cells mediate optimal protection to respiratory virus infection. J Immunol. (2011) 187:5510-4. doi: 10.4049/jimmunol.1102243

11. Schenkel JM, Fraser KA, Masopust D. Cutting edge: resident memory CD8 T cells occupy frontline niches in secondary lymphoid organs. J Immunol. (2014) 192:2961-4. doi: 10.4049/jimmunol.1400003

12. Jiang X, Clark RA, Liu L, Wagers AJ, Fuhlbrigge RC, Kupper TS. Skin infection generates non-migratory memory $\mathrm{CD}^{+} \mathrm{T}(\mathrm{RM})$ cells providing global skin immunity. Nature (2012) 483:227-31. doi: 10.1038/nature10851 
13. Marriott CL, Dutton EE, Tomura M, Withers DR. Retention of Ag-specific memory $\mathrm{CD}^{+} \mathrm{T}$ cells in the draining lymph node indicates lymphoid tissue resident memory populations. Eur J Immunol. (2017) 47:860-71. doi: 10.1002/eji.201646681

14. Wilk MM, Misiak A, McManus RM, Allen AC, Lynch MA, Mills KHG. Lung CD4 tissue-resident memory $\mathrm{T}$ cells mediate adaptive immunity induced by previous infection of mice with Bordetella pertussis. J Immunol. (2017) 199:233-43. doi: 10.4049/jimmunol.1602051

15. Gebhardt T, Palendira U, Tscharke DC, Bedoui S. Tissue-resident memory $\mathrm{T}$ cells in tissue homeostasis, persistent infection, and cancer surveillance. Immunol Rev. (2018) 283:54-76. doi: 10.1111/imr.12650

16. Park CO, Kupper TS. The emerging role of resident memory $\mathrm{T}$ cells in protective immunity and inflammatory disease. Nat Med. (2015) 21:688-97. doi: $10.1038 / \mathrm{nm} .3883$

17. Farber DL, Yudanin NA, Restifo NP. Human memory T cells: generation, compartmentalization and homeostasis. Nat Rev Immunol. (2014) 14:24-35. doi: $10.1038 /$ nri3567

18. Mackay LK, Rahimpour A, Ma JZ, Collins N, Stock AT, Hafon ML, et al. The developmental pathway for CD103(+)CD8 ${ }^{+}$tissue-resident memory T cells of skin. Nat Immunol. (2013) 14:1294-301. doi: 10.1038/ni.2744

19. Pichyangkul S, Yongvanitchit K, Limsalakpetch A, Kum-Arb U, Im-Erbsin $\mathrm{R}$, Boonnak $\mathrm{K}$, et al. Tissue distribution of memory $\mathrm{T}$ and $\mathrm{B}$ cells in rhesus monkeys following influenza A infection. J Immunol. (2015) 195:4378-86. doi: 10.4049/jimmunol.1501702

20. Reilly EC, Lambert-Emo K, Topham DJ. The effects of acute neutrophil depletion on resolution of acute influenza infection, establishment of tissue resident memory (TRM), and heterosubtypic immunity. PLoS ONE (2016) 11:e0164247. doi: 10.1371/journal.pone.0164247

21. Steinert EM, Schenkel JM, Fraser KA, Beura LK, Manlove LS, Igyarto $\mathrm{BZ}$, et al. Quantifying memory CD8 T cells reveals regionalization of immunosurveillance. Cell (2015) 161:737-49. doi: 10.1016/j.cell.2015. 03.031

22. Bergsbaken T, Bevan MJ, Fink PJ. Local inflammatory cues regulate differentiation and persistence of CD8 $(+)$ tissue-resident memory T cells. Cell Rep. (2017) 19:114-24. doi: 10.1016/j.celrep.2017.03.031

23. Shwetank, Abdelsamed HA, Frost EL, Schmitz HM, Mockus TE, Youngblood $\mathrm{BA}$, et al. Maintenance of PD-1 on brain-resident memory CD8 T cells is antigen independent. Immunol Cell Biol. (2017) 95:953-9. doi: $10.1038 /$ icb. 2017.62

24. Mackay LK, Stock AT, Ma JZ, Jones CM, Kent SJ, Mueller SN, et al. Longlived epithelial immunity by tissue-resident memory T (TRM) cells in the absence of persisting local antigen presentation. Proc Natl Acad Sci USA. (2012) 109:7037-42. doi: 10.1073/pnas.1202288109

25. Zhang N, Bevan MJ. Transforming growth factor-beta signaling controls the formation and maintenance of gut-resident memory $\mathrm{T}$ cells by regulating migration and retention. Immunity (2013) 39:687-96. doi: 10.1016/j.immuni.2013.08.019

26. Mueller SN, Gebhardt T, Carbone FR, Heath WR. Memory T cell subsets, migration patterns, and tissue residence. Annu Rev Immunol. (2013) 31:137161. doi: 10.1146/annurev-immunol-032712-095954

27. Gebhardt T, Wakim LM, Eidsmo L, Reading PC, Heath WR, Carbone FR. Memory T cells in nonlymphoid tissue that provide enhanced local immunity during infection with herpes simplex virus. Nat Immunol. (2009) 10:524-30. doi: 10.1038/ni.1718

28. Thom JT, Weber TC, Walton SM, Torti N, Oxenius A. The salivary gland acts as a sink for tissue-resident memory CD8(+) $\mathrm{T}$ Cells, facilitating protection from local cytomegalovirus infection. Cell Rep. (2015) 13:112536. doi: 10.1016/j.celrep.2015.09.082

29. Pizzolla A, Nguyen THO, Smith JM, Brooks AG, Kedzieska K, Heath WR, et al. Resident memory CD8(+) T cells in the upper respiratory tract prevent pulmonary influenza virus infection. Sci Immunol. (2017) 2:eaam6970. doi: 10.1126/sciimmunol.aam6970

30. Wu T, Hu Y, Lee YT, Bouchard KR, Benechet A, Khanna K, et al. Lung-resident memory CD8 T cells (TRM) are indispensable for optimal cross-protection against pulmonary virus infection. J Leukoc Biol. (2014) 95:215-24. doi: 10.1189/jlb.0313180

31. Lee YT, Suarez-Ramirez JE, Wu T, Redman JM, Bouchard K, Hadley GA, et al. Environmental and antigen receptor-derived signals support sustained surveillance of the lungs by pathogen-specific cytotoxic $\mathrm{T}$ lymphocytes. J Virol. (2011) 85:4085-94. doi: 10.1128/JVI.02493-10

32. Zarnitsyna VI, Handel A, McMaster SR, Hayward SL, Kohlmeier JE, Antia R. Mathematical model reveals the role of memory CD8 T cell populations in recall responses to influenza. Front Immunol. (2016) 7:165. doi: 10.3389/fimmu.2016.00165

33. Zens KD, Chen JK, Farber DL. Vaccine-generated lung tissue-resident memory $\mathrm{T}$ cells provide heterosubtypic protection to influenza infection. JCI Insight (2016) 1:e85832. doi: 10.1172/jci.insight.85832

34. Kinnear E, Lambert L, McDonald JU, Cheeseman HM, Caproni LJ, Tregoning JS. Airway T cells protect against RSV infection in the absence of antibody. Mucosal Immunol. (2018) 11:249-56. doi: 10.1038/mi.2017.46

35. Jozwik A, Habibi MS, Paras A, Zhu J, Guvenel A, Dhariwal J, et al. RSVspecific airway resident memory $\mathrm{CD} 8^{+} \mathrm{T}$ cells and differential disease severity after experimental human infection. Nat Commun. (2015) 6:10224. doi: $10.1038 /$ ncomms 10224

36. Kiniry BE, Li S, Ganesh A, Hunt PW, Somsouk M, Skinner PJ, et al. Detection of HIV-1-specific gastrointestinal tissue resident CD8(+) T-cells in chronic infection. Mucosal Immunol. (2018) 11:909-20. doi: 10.1038/mi.2017.96

37. van Aalderen MC, Remmerswaal EB, Heutinck KM, Ten Brinke A, Feltkamp MC, van der Weerd NC, et al. Clinically relevant reactivation of polyomavirus $\mathrm{BK}(\mathrm{BKPyV})$ in HLA-A02-positive renal transplant recipients is associated with impaired effector-memory differentiation of BKPyV-specific CD8 ${ }^{+} \mathrm{T}$ cells. PLoS Pathog. (2016) 12:e1005903. doi: 10.1371/journal.ppat.1005903

38. Hofmann M, Oschowitzer A, Kurzhals SR, Kruger CC, Pircher H. Thymusresident memory $\mathrm{CD}^{+} \mathrm{T}$ cells mediate local immunity. Eur J Immunol. (2013) 43:2295-304. doi: 10.1002/eji.201343519

39. Shane HL, Klonowski KD. Every breath you take: the impact of environment on resident memory CD8 T cells in the lung. Front Immunol. (2014) 5:320. doi: 10.3389/fimmu.2014.00320

40. Sathaliyawala T, Kubota M, Yudanin N, Turner D, Camp P, Thome JJ, et al. Distribution and compartmentalization of human circulating and tissue-resident memory $\mathrm{T}$ cell subsets. Immunity (2013) 38:187-97. doi: 10.1016/j.immuni.2012.09.020

41. Watanabe R, Gehad A, Yang C, Scott LL, Teague JE, Schlapbach C, et al. Human skin is protected by four functionally and phenotypically discrete populations of resident and recirculating memory T cells. Sci Transl Med. (2015) 7:279ra39. doi: 10.1126/scitranslmed.3010302

42. Thome JJ, Yudanin N, Ohmura Y, Kubota M, Grinshpun B, Sathaliyawala T, et al. Spatial map of human T cell compartmentalization and maintenance over decades of life. Cell (2014) 159:814-28. doi: 10.1016/j.cell.2014. 10.026

43. Kumar BV, Ma W, Miron M, Granot T, Guyer RS, Carpenter DJ, et al. Human tissue-resident memory $\mathrm{T}$ cells are defined by core transcriptional and functional signatures in lymphoid and mucosal sites. Cell Rep. (2017) 20:2921-34. doi: 10.1016/j.celrep.2017.08.078

44. Masopust D, Vezys V, Wherry EJ, Barber DL, Ahmed R. Cutting edge: gut microenvironment promotes differentiation of a unique memory CD8 T cell population. J Immunol. (2006) 176:2079-83. doi: 10.4049/jimmunol.176.4.2079

45. Beura LK, Wijeyesinghe S, Thompson EA, Macchietto MG, Rosato $\mathrm{PC}$, Pierson $\mathrm{MJ}$, et al. $\mathrm{T}$ cells in nonlymphoid tissues give rise to lymph-node-resident memory T cells. Immunity (2018) 48:327-38. doi: 10.1016/j.immuni.2018.01.015

46. Bergsbaken T, Bevan MJ. Proinflammatory microenvironments within the intestine regulate the differentiation of tissue-resident CD8(+) $\mathrm{T}$ cells responding to infection. Nat Immunol. (2015) 16:406-14. doi: $10.1038 /$ ni.3108

47. Kim SK, Schluns KS, Lefrancois L. Induction and visualization of mucosal memory CD8 T cells following systemic virus infection. J Immunol. (1999) 163:4125-32.

48. Stelma F, de Niet A, Sinnige MJ, van Dort KA, van Gisbergen K, Verheij $\mathrm{J}$, et al. Human intrahepatic $\mathrm{CD} 9^{+} \mathrm{CD}^{+} \mathrm{T}$ cells have a tissue resident memory T cell phenotype with reduced cytolytic capacity. Sci Rep. (2017) 7:6172. doi: 10.1038/s41598-017-06352-3

49. Wakim LM, Woodward-Davis A, Liu R, Hu Y, Villadangos J, Smyth G, et al. The molecular signature of tissue resident memory CD8 T cells isolated 
from the brain. J Immunol. (2012) 189:3462-71. doi: 10.4049/jimmunol.12 01305

50. McCully ML, Ladell K, Andrews R, Jones RE, Miners KL, Roger L, et al. CCR8 expression defines tissue-resident memory $\mathrm{T}$ cells in human skin. J Immunol. (2018) 200:1639-50. doi: 10.4049/jimmunol.1701377

51. Booth JS, Toapanta FR, Salerno-Goncalves R, Patil S, Kader HA, Safta AM, et al. Characterization and functional properties of gastric tissue-resident memory T cells from children, adults, and the elderly. Front Immunol. (2014) 5:294. doi: 10.3389/fimmu.2014.00294

52. Zens KD, Chen JK, Guyer RS, Wu FL, Cvetkovski F, Miron M, et al. Reduced generation of lung tissue-resident memory T cells during infancy. J Exp Med. (2017) 214:2915-32. doi: 10.1084/jem.20170521

53. Chang JT, Palanivel VR, Kinjyo I, Schambach F, Intlekofer AM, Banerjee A, et al. Asymmetric T lymphocyte division in the initiation of adaptive immune responses. Science (2007) 315:1687-91. doi: 10.1126/science.1139393

54. Stemberger C, Huster KM, Koffler M, Anderl F, Schiemann M, Wagner $\mathrm{H}$, et al. A single naive $\mathrm{CD}^{+} \mathrm{T}$ cell precursor can develop into diverse effector and memory subsets. Immunity (2007) 27:985-97. doi: 10.1016/j.immuni.2007.10.012

55. Jameson SC, Masopust D. Diversity in T cell memory: an embarrassment of riches. Immunity (2009) 31:859-71. doi: 10.1016/j.immuni.2009.11.007

56. Kaech SM, Tan JT, Wherry EJ, Konieczny BT, Surh CD, Ahmed R. Selective expression of the interleukin 7 receptor identifies effector CD8 $\mathrm{T}$ cells that give rise to long-lived memory cells. Nat Immunol. (2003) 4:1191-8. doi: 10.1038/ni1009

57. Sheridan BS, Pham QM, Lee YT, Cauley LS, Puddington L, Lefrancois L. Oral infection drives a distinct population of intestinal resident memory CD8(+) $\mathrm{T}$ cells with enhanced protective function. Immunity (2014) 40:747-57. doi: 10.1016/j.immuni.2014.03.007

58. Herndler-Brandstetter D, Ishigame H, Shinnakasu R, Plajer V, Stecher C, Zhao J, et al. KLRG1 ${ }^{+}$effector $\mathrm{CD}^{+}{ }^{+} \mathrm{T}$ cells lose KLRG1, differentiate into all memory $\mathrm{T}$ cell lineages, and convey enhanced protective immunity. Immunity (2018) 48:716-29. doi: 10.1016/j.immuni.2018.03.015

59. Gerlach C, Moseman EA, Loughhead SM, Alvarez D, Zwijnenburg AJ, Waanders L, et al. The chemokine receptor CX3CR1 defines three antigen-experienced $\mathrm{CD} 8 \mathrm{~T}$ cell subsets with distinct roles in immune surveillance and homeostasis. Immunity (2016) 45:1270-84. doi: 10.1016/j.immuni.2016.10.018

60. Iborra S, Martinez-Lopez M, Khouili SC, Enamorado M, Cueto FJ, Conde-Garrosa R, et al. Optimal generation of tissue-resident but not circulating memory $\mathrm{T}$ cells during viral infection requires crosspriming by DNGR-1(+) dendritic cells. Immunity (2016) 45:847-60. doi: 10.1016/j.immuni.2016.08.019

61. Laidlaw BJ, Craft JE, Kaech SM. The multifaceted role of CD4(+) T cells in CD8(+) T cell memory. Nat Rev Immunol. (2016) 16:102-11. doi: $10.1038 /$ nri.2015.10

62. Laidlaw BJ, Zhang N, Marshall HD, Staron MM, Guan T, Hu Y, et al. $\mathrm{CD}^{+} \mathrm{T}$ cell help guides formation of $\mathrm{CD} 103^{+}$lung-resident memory $\mathrm{CD}^{+} \mathrm{T}$ cells during influenza viral infection. Immunity (2014) 41:633-45. doi: 10.1016/j.immuni.2014.09.007

63. Zaid A, Mackay LK, Rahimpour A, Braun A, Veldhoen M, Carbone FR, et al. Persistence of skin-resident memory T cells within an epidermal niche. Proc Natl Acad Sci USA. (2014) 111:5307-12. doi: 10.1073/pnas.1322292111

64. Mackay LK, Minnich M, Kragten NA, Liao Y, Nota B, Seillet C, et al. Hobit and Blimp1 instruct a universal transcriptional program of tissue residency in lymphocytes. Science (2016) 352:459-63. doi: 10.1126/science.aad2035

65. Boddupalli CS, Nair S, Gray SM, Nowyhed HN, Verma R, Gibson JA, et al. $\mathrm{ABC}$ transporters and NR4A1 identify a quiescent subset of tissue-resident memory T cells. J Clin Invest. (2016) 126:3905-16. doi: 10.1172/JCI85329

66. Milner JJ, Toma C, Yu B, Zhang K, Omilusik K, Phan AT, et al. Runx3 programs $\mathrm{CD} 8(+) \mathrm{T}$ cell residency in non-lymphoid tissues and tumours. Nature (2017) 552:253-7. doi: 10.1038/nature24993

67. Borges da Silva H, Beura LK, Wang H, Hanse EA, Gore R, Scott MC, et al. The purinergic receptor $\mathrm{P} 2 \mathrm{RX} 7$ directs metabolic fitness of long-lived memory $\mathrm{CD}^{+}$T cells. Nature (2018) 559:264-8. doi: 10.1038/s41586-018-0282-0

68. Zammit DJ, Turner DL, Klonowski KD, Lefrancois L, Cauley LS. Residual antigen presentation after influenza virus infection affects
CD8 $\mathrm{T}$ cell activation and migration. Immunity (2006) 24:439-49. doi: 10.1016/j.immuni.2006.01.015

69. Zhou AC, Wagar LE, Wortzman ME, Watts TH. Intrinsic 4-1BB signals are indispensable for the establishment of an influenza-specific tissue-resident memory CD8 T-cell population in the lung. Mucosal Immunol. (2017) 10:1294-309. doi: 10.1038/mi.2016.124

70. Adachi $\mathrm{T}$, Kobayashi $\mathrm{T}$, Sugihara E, Yamada $\mathrm{T}$, Ikuta $\mathrm{K}$, Pittaluga S, et al. Hair follicle-derived IL-7 and IL-15 mediate skin-resident memory T cell homeostasis and lymphoma. Nat Med. (2015) 21:1272-9. doi: $10.1038 / \mathrm{nm} .3962$

71. Ma C, Mishra S, Demel EL, Liu Y, Zhang N. TGF-beta controls the formation of kidney-resident $\mathrm{T}$ cells via promoting effector $\mathrm{T}$ cell extravasation. J Immunol. (2017) 198:749-56. doi: 10.4049/jimmunol.1601500

72. Hu Y, Lee YT, Kaech SM, Garvy B, Cauley LS. Smad4 promotes differentiation of effector and circulating memory CD8 $\mathrm{T}$ cells but is dispensable for tissue-resident memory CD8 T cells. J Immunol. (2015) 194:2407-14. doi: 10.4049/jimmunol.1402369

73. Fiege JK, Beura LK, Burbach BJ, Shimizu Y. Adhesion- and degranulationpromoting adapter protein promotes $\mathrm{CD} 8 \mathrm{~T}$ cell differentiation and resident memory formation and function during an acute infection. J Immunol. (2016) 197:2079-89. doi: 10.4049/jimmunol.15 01805

74. Zhang L, Li H, Hai Y, Yin W, Li W, Zheng B, et al. CpG in Combination with an inhibitor of notch signaling suppresses formalin-inactivated respiratory syncytial virus-enhanced airway hyperresponsiveness and inflammation by inhibiting Th17 memory responses and promoting tissue-resident memory cells in lungs. J Virol. (2017) 91:e02111-16. doi: 10.1128/JVI.02111-16

75. Graham JB, Da Costa A, Lund JM. Regulatory T cells shape the resident memory T cell response to virus infection in the tissues. J Immunol. (2014) 192:683-90. doi: 10.4049/jimmunol.1202153

76. Prasad S, Hu S, Sheng WS, Singh A, Lokensgard JR. Tregs modulate lymphocyte proliferation, activation, and resident-memory T-cell accumulation within the brain during MCMV infection. PLoS ONE (2015) 10:e0145457. doi: 10.1371/journal.pone.0145457

77. Khan TN, Mooster JL, Kilgore AM, Osborn JF, Nolz JC. Local antigen in nonlymphoid tissue promotes resident memory $\mathrm{CD}^{+} \mathrm{T}$ cell formation during viral infection. J Exp Med. (2016) 213:951-66. doi: 10.1084 /jem.20151855

78. Muschaweckh A, Buchholz VR, Fellenzer A, Hessel C, Konig PA, Tao $\mathrm{S}$, et al. Antigen-dependent competition shapes the local repertoire of tissue-resident memory CD8 ${ }^{+}$T cells. J Exp Med. (2016) 213:3075-86. doi: $10.1084 /$ jem.20160888

79. Park SL, Zaid A, Hor JL, Christo SN, Prier JE, Davies B, et al. Local proliferation maintains a stable pool of tissue-resident memory T cells after antiviral recall responses. Nat Immunol. (2018) 19:183-91. doi: 10.1038/s41590-017-0027-5

80. Wakim LM, Woodward-Davis A, Bevan MJ. Memory T cells persisting within the brain after local infection show functional adaptations to their tissue of residence. Proc Natl Acad Sci USA. (2010) 107:17872-9. doi: $10.1073 /$ pnas. 1010201107

81. Casey KA, Fraser KA, Schenkel JM, Moran A, Abt MC, Beura LK, et al. Antigen-independent differentiation and maintenance of effectorlike resident memory $\mathrm{T}$ cells in tissues. J Immunol. (2012) 188:4866-75. doi: 10.4049/jimmunol.1200402

82. Beura LK, Mitchell JS, Thompson EA, Schenkel JM, Mohammed $\mathrm{J}$, Wijeyesinghe $\mathrm{S}$, et al. Intravital mucosal imaging of $\mathrm{CD} 8(+)$ resident memory $\mathrm{T}$ cells shows tissue-autonomous recall responses that amplify secondary memory. Nat Immunol. (2018) 19:173-82. doi: $10.1038 / s 41590-017-0029-3$

83. Kaneko S, Mastaglio S, Bondanza A, Ponzoni M, Sanvito F, Aldrighetti L, et al. IL-7 and IL-15 allow the generation of suicide gene-modified alloreactive self-renewing central memory human $\mathrm{T}$ lymphocytes. Blood (2009) 113:1006-15. doi: 10.1182/blood-2008-05-156059

84. Schenkel JM, Fraser KA, Casey KA, Beura LK, Pauken KE, Vezys $\mathrm{V}$, et al. IL-15-independent maintenance of tissue-resident and boosted effector memory CD8 T cells. J Immunol. (2016) 196:3920-6. doi: 10.4049/jimmunol.1502337 
85. Mackay LK, Wynne-Jones E, Freestone D, Pellicci DG, Mielke LA, Newman $\mathrm{DM}$, et al. T-box transcription factors combine with the cytokines TGF- $\beta$ and IL-15 to control tissue-resident memory T cell fate. Immunity (2015) 43:1101-11. doi: 10.1016/j.immuni.2015.11.008

86. Mackay LK, Braun A, Macleod BL, Collins N, Tebartz C, Bedoui S, et al. Cutting edge: CD69 interference with sphingosine-1-phosphate receptor function regulates peripheral T cell retention. J Immunol. (2015) 194:205963. doi: 10.4049/jimmunol.1402256

87. Skon CN, Lee JY, Anderson KG, Masopust D, Hogquist KA, Jameson SC. Transcriptional downregulation of S1pr1 is required for the establishment of resident memory $\mathrm{CD}^{+} \mathrm{T}$ cells. Nat Immunol. (2013) 14:1285-93. doi: $10.1038 /$ ni. 2745

88. Takamura S, Yagi H, Hakata Y, Motozono C, McMaster SR, Masumoto T, et al. Specific niches for lung-resident memory $\mathrm{CD}^{+} \mathrm{T}$ cells at the site of tissue regeneration enable CD69-independent maintenance. J Exp Med. (2016) 213:3057-73. doi: 10.1084/jem.20160938

89. Woyciechowski S, Hofmann M, Pircher H. $\alpha_{4} \beta_{1}$ integrin promotes accumulation of tissue-resident memory CD8 $(+)$ T cells in salivary glands. Eur J Immunol. (2017) 47:244-50. doi: 10.1002/eji.201646722

90. Hofmann M, Pircher H. E-cadherin promotes accumulation of a unique memory CD8 T-cell population in murine salivary glands. Proc Natl Acad Sci USA. (2011) 108:16741-6. doi: 10.1073/pnas.1107200108

91. Pan Y, Tian T, Park CO, Lofftus SY, Mei S, Liu X, et al. Survival of tissueresident memory $\mathrm{T}$ cells requires exogenous lipid uptake and metabolism. Nature (2017) 543:252-6. doi: 10.1038/nature21379

92. Gaide O, Emerson RO, Jiang X, Gulati N, Nizza S, Desmarais C, et al. Common clonal origin of central and resident memory $\mathrm{T}$ cells following skin immunization. Nat Med. (2015) 21:647-53. doi: 10.1038/nm.3860

93. Pavelko KD, Bell MP, Harrington SM, Dong H. B7-H1 influences the accumulation of virus-specific tissue resident memory $\mathrm{T}$ cells in the central nervous system. Front Immunol. (2017) 8:1532. doi: 10.3389/fimmu.2017.01532

94. Ariotti S, Beltman JB, Chodaczek G, Hoekstra ME, van Beek AE, GomezEerland R, et al. Tissue-resident memory $\mathrm{CD} 8^{+} \mathrm{T}$ cells continuously patrol skin epithelia to quickly recognize local antigen. Proc Natl Acad Sci USA. (2012) 109:19739-44. doi: 10.1073/pnas.1208927109

95. Srivastava R, Hernandez-Ruiz M, Khan AA, Fouladi MA, Kim GJ, Ly VT, et al. CXCL17 chemokine-dependent mobilization of CXCR8 $(+) \operatorname{CD} 8(+)$ effector memory and tissue-resident memory $\mathrm{T}$ cells in the vaginal mucosa is associated with protection against genital herpes. J Immunol. (2018) 200:2915-26. doi: 10.4049/jimmunol.1701474

96. Srivastava R, Khan AA, Chilukuri S, Syed SA, Tran TT, Furness J, et al. CXCL10/CXCR3-dependent mobilization of herpes simplex virus-specific CD8(+) TEM and CD8(+) TRM cells within infected tissues allows efficient protection against recurrent herpesvirus infection and disease. J Virol. (2017) 91:e00278-17. doi: 10.1128/JVI.00278-17

97. Aguilar-Valenzuela R, Netland J, Seo YJ, Bevan MJ, Grakoui A, Suthar MS. Dynamics of tissue-specific $\mathrm{CD}^{+}{ }^{+} \mathrm{T}$ cell responses during West Nile virus infection. J Virol. (2018) 92:e00014-18. doi: 10.1128/JVI.00014-18
98. McMaster SR, Wilson JJ, Wang H, Kohlmeier JE. Airway-resident memory CD8 T cells provide antigen-specific protection against respiratory virus challenge through rapid IFN-gamma production. J Immunol. (2015) 195:203-9. doi: 10.4049/jimmunol.1402975

99. Shin H, Kumamoto Y, Gopinath S, Iwasaki A. CD $301 b^{+}$dendritic cells stimulate tissue-resident memory $\mathrm{CD}^{+} \mathrm{T}$ cells to protect against genital HSV-2. Nat Commun. (2016) 7:13346. doi: 10.1038/ncomms13346

100. Steinbach K, Vincenti I, Kreutzfeldt M, Page N, Muschaweckh A, Wagner I, et al. Brain-resident memory $\mathrm{T}$ cells represent an autonomous cytotoxic barrier to viral infection. J Exp Med. (2016) 213:1571-87. doi: 10.1084/jem.20151916

101. Macleod BL, Bedoui S, Hor JL, Mueller SN, Russell TA, Hollett NA, et al. Distinct APC subtypes drive spatially segregated $\mathrm{CD}^{+}{ }^{+}$and $\mathrm{CD} 8{ }^{+}{ }^{-}$-cell effector activity during skin infection with HSV-1. PLoS Pathog. (2014) 10:e1004303. doi: 10.1371/journal.ppat.1004303

102. Pauken KE, Wherry EJ. Overcoming $\mathrm{T}$ cell exhaustion in infection and cancer. Trends Immunol. (2015) 36:265-76. doi: 10.1016/j.it.2015. 02.008

103. Pallett LJ, Davies J, Colbeck EJ, Robertson F, Hansi N, Easom NJW, et al. IL-2(high) tissue-resident $\mathrm{T}$ cells in the human liver: Sentinels for hepatotropic infection. J Exp Med. (2017) 214:1567-80. doi: 10.1084/jem.201 62115

104. Ariotti S, Hogenbirk MA, Dijkgraaf FE, Visser LL, Hoekstra ME, Song JY, et al. T cell memory. Skin-resident memory CD8(+) T cells trigger a state of tissue-wide pathogen alert. Science (2014) 346:101-5. doi: $10.1126 /$ science. 1254803

105. Schenkel JM, Fraser KA, Beura LK, Pauken KE, Vezys V, Masopust D. T cell memory. Resident memory CD8 T cells trigger protective innate and adaptive immune responses. Science (2014) 346:98-101. doi: 10.1126/science.1254536

106. Tan HX, Wheatley AK, Esterbauer R, Jegaskanda S, Glass JJ, Masopust D. Induction of vaginal-resident HIV-specific CD8 T cells with mucosal prime-boost immunization. Mucosal Immunol. (2018) 11:994-1007. doi: $10.1038 / \mathrm{mi} .2017 .89$

107. Schenkel JM, Fraser KA, Vezys V, Masopust D. Sensing and alarm function of resident memory CD8(+) T cells. Nat Immunol. (2013) 14:509-13. doi: $10.1038 /$ ni.2568

Conflict of Interest Statement: The authors declare that the research was conducted in the absence of any commercial or financial relationships that could be construed as a potential conflict of interest.

Copyright (c) $2018 \mathrm{Wu}, \mathrm{Wu}$, Shen, Jiang and Xu. This is an open-access article distributed under the terms of the Creative Commons Attribution License (CC BY). The use, distribution or reproduction in other forums is permitted, provided the original author(s) and the copyright owner(s) are credited and that the original publication in this journal is cited, in accordance with accepted academic practice. No use, distribution or reproduction is permitted which does not comply with these terms. 